GEOGRAFICKÝ ČASOPIS / GEOGRAPHICAL JOURNAL 72 (2020) 3, 219-242

DOI: https://doi.org/10.31577/geogrcas.2020.72.3.11

\title{
WALKABILITY RESEARCH: CONCEPT, METHODS AND A CRITICAL REVIEW OF POST-SOCIALIST STUDIES
}

\author{
Katarína Rišová* \\ * Institute of Geography, Slovak Academy of Sciences, Štefánikova 49, 81473 Bratislava, Slovakia, \\ geogriso@savba.sk
}

\begin{abstract}
Walkability research: concept, methods and a critical review of post-socialist studies

The history during which a post-socialist urban environment was shaped was not pedestrian-friendly but focused on automobilization primarily. Therefore, it is important to study, measure and improve urban pedestrian areas. The main aim of this paper is to open the discussion regarding selected theories and approaches to measuring and quantifying this phenomenon, as well as to provide a bibliometric analysis and critical review of scientific records from the post-socialist countries, where the walkability concept has not yet been well-established. In conclusion, a future research agenda based on the post-socialist research limitations is proposed. The results of walkability studies can be the basis for municipal representatives to create a healthy transport environment.
\end{abstract}

Key words: walkability, post-socialist countries, bibliometric analysis, review

\section{INTRODUCTION}

Among the main dimensions of an "ecological city", the most important ones are e.g. minimization of car traffic, emphasis on walking, cycling and public transport, a compact urban form and a people-centered city center (Kenworthy 2006). Walking (as well as cycling) has been understood as a "green" mode of transport (Southworth 2005 and Rafiemanzelat et al. 2017), making it a suitable alternative for implementing the principles of sustainable urban mobility. Additionally, walkability is considered (to be) one of the basic pillars of a sustainable city and an essential part of an integrated intermodal transport system (Kenworthy 2006 and de Freitas Miranda and da Silva 2012).

However, the walkability concept has not been equally understood by all authors. On the contrary, the variability of interpretation is relatively wide. The simplest models work with walking accessibility calculations (e.g. Cervero and Kockelman 1997) while not looking at other pedestrian factors contributing to a complex commuting experience. Yet, such a simplified understanding has been met with frequent criticism. As a reaction, Blečić et al. (2015) operate with the term "quality of accessibility", the idea which rejects the time destination accessibility as a determining priority and acknowledges the importance of qualitative attributes that are often difficult to measure. Looking at walkability definitions, some authors refer to comfort, security or a visual experience (Southworth 2005 and Tsiompras and Photis 2017). However, the walking environment should not only enable passing through a particular area, but also create an opportunity to stay in and carry out various types of activities. Based on this understanding, walkability can be defined as the extent to which the environment considers various needs of pedestrians from an urban point of view. 
The social relevance of the problem consists in its contribution to the economic, environmental and social principles of sustainability applications. A walkable environment serves all public space users respecting their physical and social differences, thus equally satisfying seniors, parents with small children, impaired individuals and other groups with special needs. From the point of view of municipal representatives, results of the walkability research may become the basis for creating a healthy transport environment (Gunn et al. 2017).

One of the most fundamental aspects of the concept is the need to return public spaces to the people, which contrasts with the effects, directly or indirectly, created by motorization. However, various barriers stand in the way of this ambition, the most critical of which is probably the social acceptance of public space subordination to private cars. Indeed, car ownership and car use are closely related to the social status perception (Steg et al. 2001). Kopnina and Williams (2012), as well as Belgiawan et al. (2014) confirmed the theory that young people from lower social classes and less-developed countries show a greater desire to own a car in the future. In addition, the 1990s post-revolutionary increase in the number of cars was much more intense in Central Europe than in the more developed countries of Western Europe (Komornicki 2003). Moreover, as found by Pojani et al. (2018), in the post-socialist countries car ownership is still strongly associated with the social prestige of individuals. This is one of the reasons why it is important to discuss the walkability issue in the Central and Eastern European post-socialist environment. Additionally, in these countries, such studies are relatively rare. Moreover, they are focused on health-related research primarily while often omitting a spatial perspective. There is also a lack of interest in the research area among geographers and geoinformatics from post-socialist countries, with a few exceptions (e.g. Dobešová and Křivka 2012 and Rišová and Sládeková Madajová 2020). The main aims of the paper are therefore as follows:

- to introduce the walkability concept to geographers and other spatiallyoriented specialists, as well as to open the discussion regarding selected theories and approaches to measuring and quantifying this phenomenon;

- to provide a bibliometric analysis and critical review of scientific records from the post-socialist countries and based on their limitations define a future research agenda.

\section{THE WALKABILITY CONCEPT}

The first walkability-related scientific papers appeared at the beginning of the 1990 s with their origin in the field of urban development and concerned the quality of the urban environment and suburbs (Southworth and Owens 1993, Southworth and Ben-Joseph 1995 and Southworth 1997). It was also proved that selected environmental attributes such as population density, diversity of land use and design of streets encourage pedestrians to walk (Cervero a Kockelman 1997).

As a result, the theory of a direct link between the quality of the pedestrian environment and people's willingness to choose walking as the main transport mode is now considered valid (e.g. Ariffin and Zahari 2013 and Rafiemanzelat et al. 2017) although there are several theories supporting a critique of this idea which will be mentioned later.

Later, the walkability concept gradually become established in other research areas as well. The work of Saelens et al. (2003) examining a relationship between 
environment perception, physical activity and body weight of individuals can be considered an important milestone in the walkability research in public health. The collaboration of urban planner Lawrence D. Frank with psychology researchers was also significant. They examined a relationship between urban form and the physical activity of its inhabitants (Frank et al. 2005), neighbourhood mobility, BMI (body mass index), active modes of transport and air quality (Frank et al. 2006), as well as neighbourhood walkability, walking, car use and obesity (Frank et al. 2007).

As clarified above, the walkability research has been applied in two main research areas so far:

1. walkability as a part of an urban mobility system - applied primarily in the fields of urban planning, transportation research, urban politics, urban geography as well as transport geography. Environmental psychology and other behavioural sciences are often involved in connection with traffic behaviour and environmental perception studies;

2. walkability as encouragement of physical activity and a healthy lifestyle mostly investigated in sport science, psychology and health-related research areas.

Walking for transport as well as walking for recreation have been considered nonetheless, some researchers focus on both (e.g. Owen et al. 2007, Yang a DiezRoux 2012 and Nordh et al. 2017). Another typical research feature is that most of the papers pertain to walkability of urban areas. The exception is e.g. the study by Azmi et al. (2012) comparing the walking behaviour of individuals in rural and urban areas.

\section{Walkability as a reaction to urban motorization}

The walkability concept arose from the reaction to the negative consequences of urban motorization. The development of the concept can be divided into three stages as follows:

Stage 1 - walkability is not a new phenomenon. In the pre-industrial era when cars were not a part of a transportation system and the majority of movement was realized by foot, urban environment was naturally walkable. Southworth (2005 p. 247), who dealt with the walkability evolvement, described pre-industrial cities as settlements in which "[...] Activity patterns had to be fine grained, density of dwellings had to be relatively high, and everything had to be connected by a continuous pedestrian path network.'

Stage 2 - appearance of cars and the subsequent subordination of urban environment to motorization at the expense of pedestrians led to the pedestrian paths network discontinuity (Southworth 2005), creation of barriers, noise, air pollution, urban sprawl (Ng et al. 2015 and Rafiemanzelat et al. 2017) together with endangering the pedestrians as the most vulnerable road users (Ariffin and Zahari 2013).

Stage 3 - is characterized by efforts to correct disadvantages caused by motorization. Particular steps could be e.g. sustainable mobility plan designing, walkability research or the realization of specific actions. The actions can be implemented in various forms, from small but effective changes (e.g. small wins, sidewalk repairs, changes in street lighting) through partial restriction of car traffic to full pedestrianization in terms of transforming the streets into a pedestrian area, excluding all motorized vehicles. 


\section{Walkable city}

The term walkable or highly-walkable city has been widely used (e.g. Hoehner et al. 2005, Deehr and Shumann 2009 and Marquet and Miralles-Guasch 2015) and refers to an urbanized area in which environmental conditions for walking are highly favourable. However, the perception of a favourable pedestrian environment varies depending on particular city goals and is most often achieved by a combination of various types of car restrictions and other related solutions.

Car restrictions relate to the car ownership concept, which is considered a core factor influencing the travel mode choice (He and Thøgersen 2017) while affecting sustainable urban mobility. Low car ownership and limited parking options lead to pedestrian environment improvements (Soni and Soni 2016 and Turoń et al. 2017) and have been one of the most frequently examined topics in the context of sustainable urban mobility (e.g. Wootton 1999, Chapman 2007, Olszewski 2007, Douglas et al. 2011, Zhang et al. 2014, Ding et al. 2016 and Lanzini and Khan 2017). Problems of car ownership and car use are closely linked to traffic jams, air pollution, climate change, use of resources during the car production, health and quality of life, noise, lack of greenery, urban sprawl, the effect of urban heat island, poor social interactions, insufficient physical activity, security or lack of space (e.g., Melia 2009, Morris et al. 2009, Roshan et al. 2010, Zhao 2010, De Vos and Witlox 2013 and Nieuwenhuisen and Khreis 2016). Together with car restrictions, it is necessary to provide reasonable alternatives in terms of efficient public transport infrastructure, a sufficient cycling network and quality pedestrian areas (Soni and Soni 2016). In addition, the car-free city should provide basic services and retail within a walking distance, shelter from traffic, noise and pollution as well as space for children to play outside without supervision (Rodier and Shaheen 2003).

Other solutions consist of architectural or other functional changes that may or may not affect the existing urban form. Such actions can be e.g. to support land use mix together with a planned compact development and a high density (Frank et al. 2005, Song 2005 and Brown et al. 2007) providing short distances between destinations. The number, diversity and availability of urban facilities and amenities within a certain distance and time are also desirable (Cervero and Kockelman 1997, Ding et al. 2011 and Blečić et al. 2015), which enable the use of slow transport modes such as walking and cycling. Other actions can be e.g. improvement of the street connectivity, density and quality of pedestrian paths as well as their adaptation to the impaired or otherwise delimited individuals (De Bourdeaudhuij et al. 2003, Hajna et al. 2013 and Rice at al. 2016). Other important factors are safety and comfort, for example the presence and quality of public lighting, existence of trees and other landscaping elements or the possibility to switch to a public transport. Last but not least, the attractiveness of the pedestrian environment, providing a visual experience along the route, is also favourable (Blečić et al. 2015 and Turoń et al. 2017).

Changes affecting the existing urban form are most easily applicable in newly built urban areas, while in existing forms long-term planning is required. Some of the environmental attributes are often fixed (e.g. the existing monofunctional district with a predominance of family houses), causing limitations in achieving a highly-walkable urban areas. 


\section{Sustainability-related benefits of walkability}

Walkability is one of the fundamental pillars of a sustainable city (Southworth 2005, Ariffin and Zahari 2013 and Rafiemanzelat et al. 2017) and the benefits of a walkable environment comes from an environmental, social as well as economic dimension of a sustainable development.

In case of the environmental dimension, the positive effect lies in the cut of traffic congestion and need for parking lots, along with the reduction of noise, vibrations and air pollution ( $\mathrm{Ng}$ et al. 2015 and Turoń et al. 2017). Other benefits of a walkable city are natural resources preservation, microclimate improvement and gains of areas for public space and urban greenery (Soni and Soni 2016).

Social dimension benefits pertain to the overall quality of life improvement (Blečić et al. 2015, Jaśkiewicz and Besta 2016, Tong et al. 2016 and Zhao and Chung 2017). In particular, such improvements pertain to the mental and physical health of inhabitants, increase in the frequency and quality of social interactions, increase in safety, reduction in traffic accidents as well as in social justice, which can be seen in the availability of walking paths for all of the socio-economical classes (Southworth 2005, Ariffin and Zahari 2013, Ng et al. 2015 and Rafiemanzelat et al. 2017).

Looking at the economic dimension, walkability contributes to the improvement of the public space attractiveness, changes of spatio-temporal and consumption patterns of individuals (Castillo-Manzano et al. 2014 and Ng et al. 2015). This promotes tourism and investments and may increase employment rates. Last but not least, road infrastructure maintenance costs are eliminated (Soni and Soni 2016 and Turoń et al. 2017).

\section{WALKABILITY MEASUREMENT APPROACHES}

There are three main approaches to measuring walkability: objective, subjective and their combination. An objective approach operates with various types of models such as 3D model (Cervero and Kockelman 1997), Pedshed (Porta and Renne 2005) or commercial projects such as Walk Score (Kocher and Lerner 2007). A subjective approach, on the other hand, focuses on the perception and other behavioural variables of individuals. The most commonly used approach is a combination of the previous two.

\section{Objective approach to walkability measuring}

A 3D model and its new modifications have been used in scientific papers most frequently. This model is based on the three variables, namely: diversity - represented by the so-called land use mix (LUM), density - density of population, buildings or job opportunities and design - calculated as intersection density.

The authors of the 3D model proved that the variables mentioned above encourage walking. The original 3D model was used, for example, by Frank et al. (2005) considering population density measuring while Stockton et al. (2016) took into account housing density. The modified model was applied in the works of Frank et al. (2006) by including a proportion of a retail floor area, Saelens et al. (2003) by adding aesthetics and safety while Zandieh et al. (2017) added retail density and intensity of land use. Others who modified the original 3D model are Lee and Moudon (2006), Clark et al. (2014), but also others mentioned by Moura et al. (2017). 
When using the 3D model, LUM is calculated from selected land use categories only. The most frequently used methods of LUM calculation for the needs of walkability assessment are Frank's 3-criteria model (Frank et al. 2005) considering residential, office and commerce areas or Frank's 6-criteria model (Frank et al. 2006) taking into account single-family residential and multi-family residential areas as well as areas for education, entertainment, retail and office.

\section{Subjective approach to measuring walkability}

In case of the subjective approach, there are different evaluation schemes as well. The most widely used is NEWS (New Environment Walkability Scale), originally designed by Saelens et al. (2003), termed also as The San Diego Instrument (Brownson et al. 2004). NEWS takes a questionnaire pattern, with questions covering areas as follows:

1. population density (in this case, represented by an individual or collective housing buildings frequency of occurrence - e.g. how common are family houses in your neighborhood?),

2. land use mix (proximity of selected types of urban amenities - e.g. how far is it from your house to the nearest post office?),

and the remaining areas for which a 4-point Likert scale is used, namely:

3. simplicity or difficulty of access to selected types of urban amenities,

4. street connectivity,

5. quality of infrastructure for cycling and walking,

6. attractivity,

7. traffic safety and

8. crime safety.

There have already been various NEWS modifications. The well-known is its shortened version NEWS-A, proposed by Cerin et al. (2006 and 2009), together with its adjustment for the Chinese cities' assessment, the so-called Chinese NEWS-A (Cerin et al. 2007). Another example is the NEWS-Y proposed, by Rosenberg et al. (2009), designed for young respondents specifically. The NEWS model popularity is evidenced by the numerous scientific works (e.g. Leslie et al. 2005, Adams et. al. 2009, Gebel et al. 2011, Qureshi et al. 2018 and MartínezMartínez and Ramírez-López 2018).

There are also complex subjective approaches considering the full range of subjective criteria (e.g. King et al. 2003 and Azmi and Karim 2012). On the other hand, other approaches can focus on one criterion solely or a small group of indicators. The example of such an approach can be a study based on different types of barriers perception (Strohmeier 2016). As a complementary method, mental maps, mostly to examine the relationship between walkability and the spatial cognition of children (Moran et al. 2017), the perception of the neighborhood of seniors (Bödeker 2018) or in any other suitable cases, can be used.

\section{Critique of approaches to measuring walkability}

Both of the above-mentioned approaches are subject to critique. In the case of the subjective approach, the accuracy of data stated by respondents is the most commonly questioned aspect, since it can lead to measurement errors and biases (Wang and Yang 2019). 
Looking at the objective approach, the models are often considered too simplified. There is also evidence that the 3D model is not valid universally. Salvo et al. (2014) calculated a walkability index in Cuernavaca (Mexico). The index consisted of population density, street connectivity, LUM and the share of retail space areas, with the first three variables being part of the $3 \mathrm{D}$ model. In contrast with the widely accepted knowledge, in the more walkable areas there was recorded the lower physical activity of individuals. Similar research in Hong Kong (Lu et al. 2017) did not reveal any significant relationship between LUM, street connectivity and walking. In that case, population density had a positive effect on walking in the case of moderately dense populated areas only. In the case of the highest population density recorded in the area examined, the density had a negative effect on walking. Other findings from Nanjing ( $\mathrm{Xu}$ et al. 2010) indicate that there may be a negative association between population density and physical activity. The results of Xu et al. (2010) and Lu et al. (2017) showed that the most favourable walkability values are in the moderately populated areas, which can be caused by a lack of open public space and recreational urban amenities as well as the perception of safety reduction. Such findings indicate the existence of a population density threshold effect (Lu et al. 2017). However, there are no similar results from Europe and the socalled "Western world", which may be caused by the absence of high population density values comparable with some parts of Asia.

Another critique of the objective approach is related to the theory of residential self-selection claiming that individuals can choose to live in neighborhoods that reflect their preferences for an active lifestyle, but their behaviour is not significantly changed (Giles-Corti et al. 2013). In other words, physically active individuals choose districts with higher walkability, while less physically active subjects are often satisfied with low-walkable areas. This can explain why the inhabitants of the objectively higher-rated neighborhoods walk more. The self-selection theory questions the standard approach to the walkability study which works on the assumption that the behaviour of individuals is changed by neighborhood environmental attributes. The fact that individuals choose their place of residence also according to walkability was confirmed, for example, by van Dyck et al. (2011) or Christiansen et al. (2014). Based on this theory, the biases of results were found by e.g. Scheiner and Holz-Rau (2007) and Christiansen et al. (2014). Moreover, residential self-selection theory was addressed by numerous other scientific papers on walkability (Bhat and Guo 2007, Mokhtarian and Cao 2008, Næss 2009, BooneHeinonen et al. 2011, Yu and Zhu 2015 and Lindelöw et al. 2017).

\section{BIBLIOMETRIC ANALYSIS AND A CRITICAL REVIEW OF A WALKABILITY RESEARCH IN THE POST-SOCIALIST COUNTRIES}

\section{Methods}

A Web of Science Core Collection data valid for 21st of May 2020 was generated and processed in the analysis. The key word used for the Web of Science search was "walkability". Together, 2,163 records were found, of which 57 had at least one co-author from a post-socialist country. Because of the assumption of a lower number of records by researchers from post-socialist countries, the time period for search was not specified, to ensure that all the records will be found. For the same reason, all the records including articles, proceedings papers and meeting abstracts 
were considered. Using the VOS viewer network visualization, which is a software for constructing and visualizing bibliometric networks, the terms were extracted by title and abstract fields with a minimum number of 6 occurrences. The terms were then clustered and linked to each other according to their co-occurrence, which is visualized by the size of the lines. The size of the circles and labels depend on a weight (occurrence) of a particular key word. The critical review is focused mainly on the research areas, methods and participants chosen for the research with an emphasis on their limitation detection.

\section{Results and discussion}

Although several post-socialist countries have participated in the walkability research so far (Tab. 1), the most productive were scientists from the Czechia, with publications focused solely on health issues and published in health-related journals, with the exception of one proceedings paper concerned to the GIS-based pedestrian network optimization (Mudron̆ and Pachta 2013). The majority of the papers have their origin at the Palacký University Olomouc (25 records).

Tab. 1. List of the countries according to the number of documents

\begin{tabular}{lc|lc}
\hline Countries & Record Count & Countries & Record Count \\
\hline Czechia & 28 & Slovakia & 2 \\
Poland & 8 & Slovenia & 2 \\
Estonia & 5 & Albania & 1 \\
Hungary & 5 & Croatia & 1 \\
Lithuania & 5 & Romania & 1 \\
Serbia & 2 & Russia & 1 \\
\hline
\end{tabular}

Source: Web of Science Core Collection 21.5.2020.

\section{Research areas and methods in the post-socialist walkability research}

As shown in Tab. 2, most of the research was published in journals concerning the physical and mental health of people. On the contrary, development of urban areas played a less important role and was not the focus of interest in post-socialist countries. Even global records concern the health-related walkability issues primarily, however, there has been an effort to address other topics as well. Moreover, the source titles are less evenly represented in post-socialist countries compared to the global records.

Tab. 2. Overview of the most frequent source titles

\begin{tabular}{lcr}
\hline Source titles & Records & \% of 57 \\
\hline International Journal of Environmental Research and Public Health & 7 & 12.28 \\
International Journal of Behavioral Nutrition and Physical Activity & 6 & 10.53 \\
Acta Gymnica & 3 & 5.26 \\
Preventive Medicine & 3 & 5.26 \\
Bmc Public Health & 2 & 3.51 \\
Central European Journal of Public Health & 2 & 3.51 \\
Environmental Health Perspectives & 2 & 3.51 \\
Health \& Place & 2 & 3.51 \\
International Journal of Health Geographics & 2 & 3.51 \\
Journal of Physical Activity \& Health & 2 & 3.51 \\
Obesity Reviews & 2 & 3.51 \\
\hline
\end{tabular}

Source: Web of Science Core Collection 21.5.2020. 
Looking at the VOS viewer Network visualization (Fig. 1), the key words relate primarily to the general walkability-related words (red cluster) and various environmental attributes connected to the health issues (blue and green cluster). The occurrence of terms from behavioural science was in most cases limited to the yellow cluster and was not strongly related to the other items.

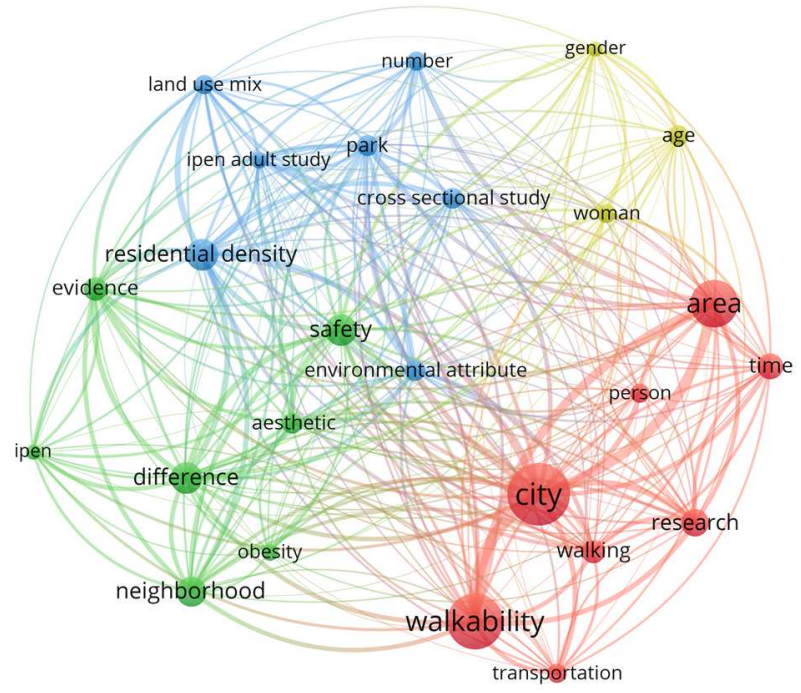

Fig. 1. Network visualization showing co-occurrence of key words in papers with at least one author from a post-socialist country

Source: Web of Science Core Collection 21.5.2020.

\section{Health-related topics}

Most of the records concerned a connection between walkability and physical activity of individuals, looking at walking, cycling or movement behaviour in general. Of that, a significant amount of research was conducted during the IPEN project (International Physical Activity and Environment Network Study), which is a multiple country network aiming to gain data for joint analyses through the common methods and measures implementation. From the post-socialist countries, scientist from the Czechiawere the most active in the study. Other members of the network from the region were from Poland, Serbia and Slovenia. Data comparability and a large number of participants allow for generally valid conclusions to be drawn. However, such research is subject to a number of limitations. As the topics and research questions in all the IPEN-related articles are similar, the variability of the acquired knowledge is not rich. Moreover, the research is focused on the "average adult" solely which omits other city inhabitants and users. There are also other works examining the relationship between walking environment and physical activity that are not part of the IPEN project. The common constraints of the nonIPEN papers are e.g. a limited number of participants and research conducted in a small area only. The exceptions are e.g. Compernolle et al. (2016a) who conducted a research with 5,205 adults in 5 different regions across Europe, Pelclová et al. 
(2014) whose research involved 1,422 older women as well as Rubín et al. (2015) who considered responses of 23,621 participants in the Czech National Population and Housing Census 2011.

In general, most of the walkability vs. physical activity studies are based on two main data types. First, there is walkability-related data either using the NEWS/ ANEWS methodology of the subjective environmental perception (e.g. Pelclová et al. 2012, Mitáš et al. 2013, Owen et al. 2018 and Cuberek et al. 2019) or implementing methods of obtaining the objective data, including the 3D model or other methods of walkability index calculation (e.g. Buck et al. 2015 and 2019, Christiansen et al. 2016, Cerin et al. 2017 and Sun et al. 2020b). Second, the physical activity data can be device-based using a pedometer or accelerometer (e.g. Cuberek et al. 2019, Buck et al. 2015 and 2019, Dygrýn et al. 2010, Sigmundová et al. 2011, Cerin et al. 2017 and Owen et al. 2018) or self-reported (e.g. Sun et al. 2020b, Pelclová et al. 2012, Mitáš et al. 2013 and Christiansen et al. 2016).

Common shortcoming of such papers is a simplified research question, often focused solely on the association between environmental conditions and walking with a lack of variables considered. Few exceptions are some of the non-IPENrelated papers adding other factors as well, such as BMI (Dygrýn et al. 2010, Sigmundová et al. 2011 and Compernolle et al. 2016b), age, education, safety concerns of parents and season (Buck et al. 2015). Another exception is a work by Compernolle et al. (2016a) who, despite using walkability and physical activity data only, chose the original way of data collection - combining the perception of safety, aesthetics, destinations and functionality of the walking environment with objective observations using the Google Street View virtual audit and online survey regarding movement behaviour.

However, some of the health-related topics are focused on other issues. As an example, Sofková et al. (2013) examined the association between walkability and body composition in obese and overweight women. Other obesity-related papers were those by Roda et al. (2016) and Mackenbach et al. (2016). Walkability has also been considered as one of the factors of environmental exposure influencing child development during pregnancy (Robinson et al. 2018 and Agier et al. 2019).

\section{Non-health-related topics}

There has been a limited number of the post-socialist authors dealing with nonhealth related walkability research questions and topics. Additionally, some of them understand the concept of walkability in a simplified way: equally to accessibility or walking distance. That is the case of records pertaining to the modelling of walking accessibility to amenities (Tiran et al. 2019), modeling of the optimal pedestrian network (Mudron̆ and Pachta 2013) and research concerned the urban green spaces distribution (Silva et al. 2018). Other works focused on walking of youth either in association with a perceived safety using NEWS-A walkability data and IPAQ form to quantify physical activity (Mitáš et al. 2018) or examining temporal changes in active commuting to school in different built environments applying a basic 3D model together with commuting data from the Czech Census of Population and Housing 2001 and 2011 (Dygrýn et al. 2015). The conventionally used methods implemented in these two papers and applied to thousands of participants allow us to reveal more reliable results which are comparable with other studies. On the other hand, such an approach can be considered impoverished by a 
lack of new or more creative approaches. In contrast, Jaśkiewicz and Besta (2014) used several behavioural methods in addition to NEWS to reveal the relationship between walkability and satisfaction with life. At the same time, a sufficient number of participants was involved in the study, exceeding 600 individuals. In another study, Szücs et al. (2017) involved not only participant observations and a questionnaire, but also interviews with local stakeholders and policy makers to uncover opportunities for walkability in two middle-sized European cities of Szeged and Valencia.

Even with these topics, there is space for international collaborations (e.g. Porębska et al. 2019 and Sun et al. 2020a). In some cases, the subject of the cooperation is the comparison of the results from two different cities or countries, such as the Czechia and Poland (Mitáš et al. 2018), Faro and Tartu (Silva et al. 2018) as well as Novi Sad and Koper (Farkić et al. 2015). Other examples are comparative studies of cities located in the same countries, however, without foreign scientists involved. This way, Tri-city agglomeration in Poland (Jaśkiewicz and Besta 2014), same as cities of Olomouc and Hradec Králové in the Czechia (Dygrýn et al. 2015) were examined.

\section{Methodological and theoretical walkability papers by post-socialist authors}

Lastly, post-socialist authors have published methodological as well as theoretical papers concerning walkability issues. While the first of them pertains to the development and validity evaluations of NEWS modifications (Jaśkiewicz and Besta 2016 and Cerin et al. 2019), the second category is devoted to the critical insights in implementing sustainable mobility plans and strategies in particular cities from the urban planning point of view. The advantage of spatial planning papers can be seen in the describing of the initiatives in implementing various practices types and pointing to the problems of political will. However, such articles often omit a research review and discussion with other authors' findings (e.g. Turoń et al. 2017 and Kamrowska-Załuska 2018). The exception is a paper by van Hoof et al. (2018) whose work includes not only an overview of projects for older people in Cracow and The Hague, but also a review of the relevant scientific literature.

\section{Participants and focus groups in the post-socialist walkability research}

Even in the western walkability literature, there has been a limited attention to the diversity of abilities and ages, which is evidenced in the review of Stafford and Baldwin (2018). This leads to the dominant group prioritization and standardization of planning and design of neighbourhoods. Everyone not considered an "average adult" is therefore vulnerable to planning marginalization.

According to evidence of Dumbaugh (2008) and Webb et al. (2017), the walking speed of an average adult is different compared to people with mobility impairments and seniors. Additionally, different groups perceive and encounter different barriers on the route (e.g. Huertas-Delgado et al. 2019 and Routhier et al. 2019). Of the 57 papers examined, only 4 of them focused on the older adults and agefriendly cities (Pelclová et al. 2012 and 2014, van Hoof et al. 2018 and Cuberek et al. 2019) and two studies pertained to the small children primarily (Buck et al. 2015 and 2019). Youth was examined by some authors as well (e.g. Dygrýn et al. 
2015, Cerin et al. 2019 and Mitáš et al. 2018). Although youth may have different preferences regarding a walkable environment, their walking abilities are not as much different compared to an "average adult". With a few exceptions, we did not observe studies combining several age categories at once. One of the exceptions is a remarkable study pertaining to the children quantifying differences of trajectories over age, and thus comparing various life stages from 3 to 15 years old individuals (Buck et al. 2019). However, as a limitation, only traditional objective walkability variables were used in this study, with no attempt to implement qualitative methods. On the other hand, not a single record deals with a sensory, cognitive or mobility impairments, which is a significant difference compared to the western research. Other topics are also neglected, such as walking of mothers on maternity leave.

\section{CONCLUSIONS AND FUTURE RESEARCH AGENDA}

In the early stages of the walkability research, the studies were conducted primarily in the field of urban planning, using objective indicators solely. However, the walkability concept has later began to be linked to the sphere of public health and physical activity of individuals. Current research focuses primarily on health, social and behavioural aspects of walkability. Comprehensive studies, however, require a certain degree of knowledge of several more scientific fields, such as behavioural studies, geography, social sciences as well as economy. For instance, behavioural sciences enable to examine the connections between characteristics of an individual and his spatial behaviour. This way, e.g. spatio-temporal patterns, gender differences in walking behaviour or the travel mode choice can be clarified. Geography brings a spatial approach to the problem and the possibility of using analytical GIS-based tools.

While walkability research has a long tradition in the Anglo-Saxon, Latin American, and East Asian countries, there is a lack of such studies in the postsocialist environment. In this paper, bibliographical analysis as well as critical review of the walkability-related papers by post-socialist authors were presented. In this region, the culture of the car is still typical as a symbol of social status which has been reflected in the traffic behaviour of individuals. What attention is paid to the walkability research in such a different cultural environment? To answer this question, the aim was to shed light on the specifics of the research by authors from the post-socialist countries. Based on their limitations, a future research agenda can be described as follows:

1. To increase the research topics diversity, more non-health related questions should be tested. Also, cooperation of scientists from several different disciplines is desirable, which could lead to the research findings enrichments. Interdisciplinary studies could shed light on some of the unexplored connections between healthrelated, spatial, environmental, economic as well as social aspects of walkability. There is also a need to link urban practice with relevant scientific knowledge. Therefore, in the papers written by urban planners, own research or at least a discussion between existing or proposed walkability implementations and the related scientific literature should be included.

2. Whereas the post-socialist authors rely mainly on conservative approaches to measuring walkability and physical activity, there is a gap in applying alternative 
methods. Examples of this could be a more diverse range of indicators included, alternative methods of data sampling or qualitative analysis implementation.

3. The post-socialist authors may consider minority groups during the research design creation. An example could be to avoid standardization of indicators measured, and instead adapt them to various groups with different abilities (e.g. impaired individuals), ages (e.g. children, adolescents, adults and older adults) and lifestyles (e.g. mothers on maternity leave and retired persons).

Despite the above-mentioned shortcomings, the post-socialist walkability research has also its qualities, such as international collaboration and comparative studies conduction. Although, compared to the rest of the world, the research has started with a time delay with the first record in the WOS Core Collection in 2010, it has a potential to become the basis for municipal representatives to create a healthy walking environment in the future.

This paper was supported by the Scientific Agency of the Ministry of Education, Science, Research and Sport of the Slovak Republic and the Slovak Academy of Sciences under the grant VEGA 2/0113/19.

\section{REFERENCES}

ADAMS, M. A., RYAN, S., KERR, J., SALliS, J. F., PATRICK, K., FRANK, L. D., NORMAN, G. J. (2009). Validation of the neighborhood environment walkability scale (NEWS) items using geographic information systems. Journal of Physical Activity and Health, 6, 113-123. DOI: https://doi.org/10.1123/jpah.6.s1.s113.

AGIER, L., BASAGAÑA, X., MAITRE, L., GRANUM, B., BIRD, P. K., CASAS, M., OFTEDAL, B., WRIGHT, J., ANDRUSAITYTE, S., DE CASTRO, M., CEQUIER, E., CHATZI, L., DOMAIRE-GONZALEZ, D., GRAZULEVICIENE, R., HAUG, L. S., SAKHI, A. K., LEVENTAKOU, V., MCEACHAN, R., NIEUWENHUIJSEN, M., PETRAVICIENE, I., ROBINSON, O., ROUMELIOTAKI, T., SUNYER, J., TAMAYO-URIA, I., THOMSEN, C., URQUIZA, J., VALENTIN, A., SLAMA, R., VRIJHEID, M., SIROUX, W. (2019). Early-life exposome and lung function in children in Europe: an analysis of data from the longitudinal, population-based HELIX cohort. The Lancet Planetary Health, 3(2), 81-92. DOI: https://doi.org/10.1016/S25425196(19)30010-5.

ARIFFIN, R. N. R., ZAHARI, R. K. (2013). Perceptions of the urban walking environments. Procedia-Social and Behavioral Sciences, 105, 589-597. DOI: https:// doi.org/10.1016/j.sbspro.2013.11.062.

AZMI, D. I., KARIM, H. A. (2012). A comparative study of walking behaviour to community facilities in low-cost and medium cost housing. Procedia-Social and Behavioral Sciences, 35, 619-628. DOI: https://doi.org/10.1016/j.sbspro.2012.02.129.

AZMI, D. I., KARIM, H. A., AMIN, M. Z. M. (2012). Comparing the walking behaviour between urban and rural residents. Procedia-Social and Behavioral Sciences, 68, 406416. DOI: https://doi.org/10.1016/j.sbspro.2012.12.237.

BELGIAWAN, P. F., SCHMÖCKER, J. D., ABOU-ZEID, M., WALKER, J., LEE, T. C., ETTEMA, D. F., FUJII, S. (2014). Car ownership motivations among undergraduate students in China, Indonesia, Japan, Lebanon, Netherlands, Taiwan, and USA. Transportation, 41, 1227-1244. DOI: 10.1007/s11116-014-9548-z.

BHAT, C. R., GUO, J. Y. (2007). A comprehensive analysis of built environment characteristics on household residential choice and auto ownership levels. Transportation Research: Part B-Methodological, 41, 506-526. DOI: https://doi.org/10.1016/ j.trb.2005.12.005.

BLEČ́Ć, I., CECCHINI, A., CONGIU, T., FANCELLO, G., TRUNFIO, G. A. (2015). Evaluating walkability: a capability-wise planning and design support system. Interna- 
tional Journal of Geographical Information Science, 29, 1350-1374. DOI: https:// doi.org/10.1080/13658816.2015.1026824.

BÖDEKER, M. (2018). Walking and walkability in pre-set and self-defined neighborhoods: a mental mapping study in older adults. International Journal of Environmental Research and Public Health, 15, 1363-1374. DOI: https://doi.org/10.3390/ ijerph15071363.

BOONE-HEINONEN, J., GORDON-LARSEN, P., GUILKEY, D. K., JACOBS Jr, D. R., POPKIN, B. M. (2011). Environment and physical activity dynamics: the role of residential self-selection. Psychology of Sport and Exercise, 12, 54-60. DOI: https:// doi.org/10.1016/j.psychsport.2009.09.003.

BROWN, B. B., WERNER, C. M., AMBURGEY, J. W., SZALAY, C. (2007). Walkable route perceptions and physical features: Converging evidence for en route walking experiences. Environment and Behavior, 39, 34-61. DOI: https:// doi.org/10.1177/0013916506295569.

BROWNSON, R. C., CHANG, J. J., EYLER, A. A., AINSWORTH, B. E., KIRTLAND, K. A., SAELENS, B. E., SALLIS, J. F. (2004). Measuring the environment for friendliness toward physical activity: a comparison of the reliability of 3 questionnaires. American Journal of Public Health, 94, 473-483. DOI: https://doi.org/10.2105/ AJPH.94.3.473.

BUCK, C., EIBEN, G., LAURIA, F., KONSTABEL, K., PAGE, A., AHRENS, W., PIGEOT, I. (2019). Urban moveability and physical activity in children: longitudinal results from the IDEFICS and I.Family cohort. International Journal of Behavioral Nutrition and Physical Activity, 16, 128. DOI: https://doi.org/10.1186/s12966-019-0886-2.

BUCK, C., KNEIB, T., TKACZICK, T., KONSTABEL, K., PIGEOT, I. (2015). Assessing opportunities for physical activity in the built environment of children: interrelation between kernel density and neighborhood scale. International Journal of Health Geographics, 14, 35. DOI: https://doi.org/10.1186/s12942-015-0027-3.

CASTILLO-MANZANO, J. I., LOPEZ-VALPUESTA, L., ASENCIO-FLORES, J. P. (2014). Extending pedestrianization processes outside the old city center; conflict and benefits in the case of the city of Seville. Habitat International, 44, 194-201. DOI: https://doi.org/10.1016/j.habitatint.2014.06.005.

CERIN, E., CONWAY, T. L., BARNETT, A., SMITH, M., VEITCH, J., CAIN, K. L., SALONNA, F., REIS, R. S., MOLINA-GARCIA, J., HINCKSON, E., MUDA, W. A. M. W., ANJANA, R. M., VAN DYCK, D., OYEMI, A. L., TIMPERIO, A., CHRISTIANSEN, L. B., MITÁŠ, J., MOTA, J., MORAN, M., ISLAM, M. Z., MELLECKER, R. R., SALLIS, J. F. (2019). Development and validation of the neighborhood environment walkability scale for youth across six continents. International Journal of Behavioral Nutrition and Physical Activity, 16, 122. DOI: https://doi.org/10.1186/s12966-019-0890 $-6$.

CERIN, E., CONWAY, T. L., SAELENS, B. E., FRANK, L. D., SALLIS, J. F. (2009). Cross-validation of the factorial structure of the Neighborhood Environment Walkability Scale (NEWS) and its abbreviated form (NEWS-A). International Journal of Behavioral Nutrition and Physical Activity, 6, 32. DOI: https://doi.org/10.1186/1479-5868-632.

CERIN, E., MACFARLANE, D. J., KO, H. H., CHAN, K. C. A. (2007). Measuring perceived neighbourhood walkability in Hong Kong. Cities, 24, 209-217. DOI: https:// doi.org/10.1016/j.cities.2006.12.002.

CERIN, E., MITÁŠ́, J., CAIN, K. L., CONWAY, T. L., ADAMS, M. A., SCHOFIELD, G., SARMIENTO, O. L., REIS, R. S., SCHIPPERIJN, J., DAVEY, R., SALVO, D., ORZANCO-GARRALDA, R., MACFARLANE, D. J., De BOURDEAUDHUIJ, I., OWEN, N., SALLIS, J. F., Van DYCK, D. (2017). Do associations between objectively -assessed physical activity and neighbourhood environment attributes vary by time of the day and day of the week? IPEN adult study. International Journal of Behavioral Nutrition and Physical Activity, 14, 34. DOI: https://doi.org/10.1186/s12966-017-0493-z. 
CERIN, E., SAELENS, B. E., SALLIS, J. F., FRANK, L. D. (2006). Neighborhood environment walkability scale: Validity and development of a short form. Medicine \& Science in Sports \& Exercise, 38, 1682-1691. DOI: 10.1249/01.mss.0000227639.83607.4d.

CERVERO, R., KOCKELMAN, K. (1997). Travel demand and the 3Ds: density, diversity, and design. Transportation Research: Part D Transport and Environment, 2, 199-219. DOI: 10.1016/S1361-9209(97)00009-6.

CHAPMAN, L. (2007). Transport and climate change: a review. Journal of Transport Geography, 15, 354-367. DOI: https://doi.org/10.1016/j.jtrangeo.2006.11.008.

CHRISTIANSEN, L. B., CERIN, E., BADLAND, H., KERR, J., DAVEY, R., TROELSEN, J., Van DYCK, D., MITÁS̆, J., SCHOFIELD, G., SUGIYAMA, T., SALVO, D. SARMIENTO, O. L., REIS, R., ADAMS, M., FRANCK, L., SALLIS, J. F. (2016). International comparisons of the associations between objective measures of the built environment and transport-related walking and cycling: IPEN adult study. Journal of Transport \& Health, 3, 467-478. DOI: https://doi.org/10.1016/j.jth.2016.02.010.

CHRISTIANSEN, L. B., MADSEN, T., SCHIPPERIJN, J., ERSBØLL, A. K., TROELSEN, J. (2014). Variations in active transport behavior among different neighborhoods and across adult life stages. Journal of Transport \& Health, 1, 316-325. DOI: https://doi.org/10.1016/j.jth.2014.10.002.

CLARK, A. F., SCOTT, D. M., YIANNAKOULIAS, N. (2014). Examining the relationship between active travel, weather, and the built environment: a multilevel approach using a GPS-enhanced dataset. Transportation, 41, 325-338. DOI: https:// doi.org/10.1007/s11116-013-9476-3.

COMPERNOLLE, S., De COCKER, K., RODA, C., OPPERT, J. M., MACKENBACH, J. D., LAKERVELD, J., GLONTI, K., BARDOS, H., RUTTER., H., CARDON, G., De BOURDEAUDHUIJ, I. (2016a). Physical environmental correlates of domain-specific sedentary behaviours across five European regions (the SPOTLIGHT Project). PLoS One, 11, e0164812. DOI: https://doi.org/10.1371/journal.pone.0164812.

COMPERNOLLE, S., OPPERT, J. M., MACKENBACH, J. D., LAKERVELD, J., CHARREIRE, H., GLONTI, K., BARDOS, H., RUTTER, H., DE COCKER, K., CARDON, G., De BOURDEAUDHUIJ, I. (2016b). Mediating role of energy-balance related behaviors in the association of neighborhood socio-economic status and residential area density with BMI: The SPOTLIGHT study. Preventive Medicine, 86, 84-91. DOI: https://doi.org/10.1016/j.ypmed.2016.01.005.

CUBEREK, R., PELCLOVÁ, J., GÁBA, A., PECHOVÁ, J., SVOZILOVÁ, Z., PŘIDALOVẢ, M., ŠTEFELOVÁ, N., HRON, K. (2019). Adiposity and changes in movement-related behaviors in older adult women in the context of the built environment: a protocol for a prospective cohort study. BMC Public Health, 19(1), 1-7. DOI: https://doi.org/10.1186/s12889-019-7905-8.

De BOURDEAUDHUIJ, I., SALLIS, J. F., SAELENS, B. E. (2003). Environmental correlates of physical activity in a sample of Belgian adults. A merican Journal of Health Promotion, 18(1), 83-92. DOI: https://doi.org/10.4278/0890-1171-18.1.83.

De FREITAS MIRANDA, H., da SILVA, A. N. R. (2012). Benchmarking sustainable urban mobility: The case of Curitiba, Brazil. Transport Policy, 21, 141-151. DOI: https:// doi.org/10.1016/j.tranpol.2012.03.009.

De VOS, J., WITLOX, F. (2013). Transportation policy as spatial planning tool; reducing urban sprawl by increasing travel costs and clustering infrastructure and public transportation. Journal of Transport Geography, 33, 117-125. DOI: https://doi.org/10.1016/ j.jtrangeo.2013.09.014.

DEEHR, R. C., SHUMANN, A. (2009). Active Seattle: achieving walkability in diverse neighborhoods. American Journal of Preventive Medicine, 37, 403-411. DOI: https:// doi.org/10.1016/j.amepre.2009.09.026.

DING, C., WANG, Y., TANG, T., MISHRA, S., LIU, C. (2016). Joint analysis of the spatial impacts of built environment on car ownership and travel mode choice. Transportation Research Part D: Transport and Environment, 60, 28-40. DOI: https:// doi.org/10.1016/j.trd.2016.08.004. 
DING, D., SALLIS, J. F., KERR, J., LEE, S., ROSENBERG, D. E. (2011). Neighborhood environment and physical activity among youth: a review. American Journal of Preventive Medicine, 41, 442-455. DOI: https://doi.org/10.1016/j.amepre.2011.06.036.

DOBEŠOVÁ, Z., KŘIVKA, T. (2012). Walkability index in the urban planning: A case study in Olomouc city. In Burian, J., ed. Advances in Spatial Planning. Rijeka (InTech), pp. 179-197.

DOUGLAS, M. J., WATKINS, S. J., GORMAN, D. R., HIGGINS, M. (2011). Are cars the new tobacco? Journal of Public Health, 33, 160-169. DOI: https://doi.org/10.1093/ pubmed/fdr032.

DUMBAUGH, E. (2008). Designing communities to enhance the safety and mobility of older adults: A universal approach. Journal of Planning Literature, 23, 17-36. DOI: https://doi.org/10.1177/0885412208318559.

DYGRÝN, J., MITÁS̆ , J., STELZER, J. (2010). The influence of built environment on walkability using geographic information system. Journal of Human Kinetics, 24, 9399. DOI: https://doi.org/10.2478/v10078-010-0025-2.

DYGRÝN, J., MITÁŚ, J., GÁBA, A., RUBÍN, L., FRÖMEL, K. (2015). Changes in active commuting to school in Czech adolescents in different types of built environment across a 10-year period. International Journal of Environmental Research and Public Health, 12, 12988-12998. DOI: https://doi.org/10.3390/ijerph121012988.

FARKIĆ, J., PERIĆ, D., LESJAK, M., PETELIN, M. (2015). Urban walking: Perspectives of locals and tourists. Geographica Pannonica, 19, 212-222. DOI: 10.5937/ GeoPan1504212F.

FRANK, L. D., SAELENS, B. E., POWELL, K. E., CHAPMAN, J. E. (2007). Stepping towards causation: do built environments or neighborhood and travel preferences explain physical activity, driving, and obesity? Social Science \& Medicine, 65, 18981914. DOI: https://doi.org/10.1016/j.socscimed.2007.05.053.

FRANK, L. D., SALLIS, J. F., CONWAY, T. L., CHAPMAN, J. E., SAELENS, B. E., BACHMAN, W. (2006). Many pathways from land use to health: associations between neighborhood walkability and active transportation, body mass index, and air quality. Journal of the American Planning Association, 72, 75-87. DOI: https:// doi.org/10.1080/01944360608976725.

FRANK, L. D., SCHMID, T. L., SALLIS, J. F., CHAPMAN, J., SAELENS, B. E. (2005). Linking objectively measured physical activity with objectively measured urban form. American Journal of Preventive Medicine, 28, 117-125. DOI: https://doi.org/10.1016/ j.amepre.2004.11.001.

GEBEL, K., BAUMAN, A. E., SUGIYAMA, T., OWEN, N. (2011). Mismatch between perceived and objectively assessed neighborhood walkability attributes: prospective relationships with walking and weight gain. Health \& Place, 17, 519-524. DOI: https:// doi.org/10.1016/j.healthplace.2010.12.008.

GILES-CORTI, B., BULL, F., KNUIMAN, M., MCCORMACK, G., Van NIEL, K., TIMPERIO, A., CHRISTIAN, H., FOSTER, S., DIVITINI, M., MIDDLETON, N., BORUFF, B. (2013). The influence of urban design on neighbourhood walking following residential relocation: longitudinal results from the RESIDE study. Social Science \& Medicine, 77, 20-30. DOI: https://doi.org/10.1016/j.socscimed.2012.10.016.

GUNN, L. D., MAVOA, S., BOULANGÉ, C., HOOPER, P., KAVANAGH, A., GILESCORTI, B. (2017). Designing healthy communities: creating evidence on metrics for built environment features associated with walkable neighbourhood activity centres. International Journal of Behavioral Nutrition and Physical Activity, 14, 164-175. DOI: https://doi.org/10.1186/s12966-017-0621-9.

HAJNA, S., DASGUPTA, K., HALPARIN, M., ROSS, N. A. (2013). Neighborhood walkability: field validation of geographic information system measures. American Journal of Preventive Medicine, 44(6), 55-59. DOI: https://doi.org/10.1016/j.amepre. 2013.01.033. 
HE, S. Y., THØGERSEN, J. (2017). The impact of attitudes and perceptions on travel mode choice and car ownership in a Chinese megacity: The case of Guangzhou. Research in Transportation Economics, 62, 57-67. DOI: https://doi.org/10.1016/ j.retrec.2017.03.004.

HOEHNER, C. M., RAMIREZ, L. K. B., ELLIOTT, M. B., HANDY, S. L., BROWNSON, R. C. (2005). Perceived and objective environmental measures and physical activity among urban adults. American Journal of Preventive Medicine, 28, 105-116. DOI: https://doi.org/10.1016/j.amepre.2004.10.023.

HUERTAS-DELGADO, F. J., MOLINA-GARCÍA, J., Van DYCK, D., CHILLÓN, P. (2019). A questionnaire to assess parental perception of barriers towards active commuting to school (PABACS): Reliability and validity. Journal of Transport \& Health, 12, 97-104. DOI: https://doi.org/10.1016/j.jth.2018.12.004.

JAŚKIEWICZ, M., BESTA, T. (2014). Is easy access related to better life? Walkability and overlapping of personal and communal identity as predictors of quality of life. Applied Research in Quality of Life, 9, 505-516. DOI: https://doi.org/10.1007/s11482-013-92466.

JAŚKIEWICZ, M., BESTA, T. (2016). Polish version of the neighbourhood environment walkability scale (NEWS-Poland). International Journal of Environmental Research and Public Health, 13, 1090-1113. DOI: https://doi.org/10.3390/ijerph13111090.

KAČALA, J., PISARČÍKOVÁ, M., POVAŽAJ, M., eds. (2003). Krátky slovník slovenského jazyka, 4. dopl. a upr. vyd. Bratislava (Veda).

KAMROWSKA-ZAŁUSKA, D. D. (2018). Buenos Aires - toward comprehensive development and sustainable mobility. In IOP Conference Series: Materials Science and Engineering, IOP Publishing, pp. 1-16. DOI: 10.1088/1757-899X/245/6/062022.

KENWORTHY, J. R. (2006). The eco-city: Ten key transport and planning dimensions for sustainable city development. Environment and Urbanization, 18, 67-85. DOI: https:// doi.org/10.1177/0956247806063947.

KING, W. C., BRACH, J. S., BELLE, S., KILLINGSWORTH, R., FENTON, M., KRISKA, A. M. (2003). The relationship between convenience of destinations and walking levels in older women. American Journal of Health Promotion, 18, 74-82. DOI: https://doi.org/10.4278/0890-1171-18.1.74.

KOCHER, J., LERNER, M. (2007). Walkscore, [Online]. Available: https//walkscore.com/. [accessed 21 June 2020].

KOMORNICKI, T. (2003). Factors of development of car ownership in Poland. Transport Reviews, 23(4), 413-431. DOI: 10.1080/0144164022000026936.

KOPNINA, H., WILLIAMS, M. (2012). Car attitudes in children from different socioeconomic backgrounds in the Netherlands. Transport Policy, 24, 118-125. DOI: https:// doi.org/10.1016/j.tranpol.2012.07.010.

LANZINI, P., KHAN, S. A. (2017). Shedding light on the psychological and behavioral determinants of travel mode choice: A meta-analysis. Transportation Research Part F: Traffic Psychology and Behaviour, 48, 13-27. DOI: https://doi.org/10.1016/ j.trf.2017.04.020.

LEE, C., MOUDON, A. V. (2006). The 3Ds+ R: Quantifying land use and urban form correlates of walking. Transportation Research Part D: Transport and Environment, 11, 204-215. DOI: https://doi.org/10.1016/j.trd.2006.02.003.

LESLIE, E., SAELENS, B., FRANK, L., OWEN, N., BAUMAN, A., COFFEE, N., HUGO, G. (2005). Residents' perceptions of walkability attributes in objectively different neighbourhoods: a pilot study. Health \& Place, 11, 227-236. DOI: https:// doi.org/10.1016/j.healthplace.2004.05.005.

LINDELÔW, D., SVENSSON, Å., BRUNDELL-FREIJ, K., HISELIUS, L. W. (2017). Satisfaction or compensation? The interaction between walking preferences and neighbourhood design. Transportation Research Part D: Transport and Environment, 50, 520 532. DOI: https://doi.org/10.1016/j.trd.2016.11.021. 
LU, Y., XIAO, Y., YE, Y. (2017). Urban density, diversity and design: Is more always better for walking? A study from Hong Kong. Preventive Medicine, 103, 99-103. DOI: https://doi.org/10.1016/j.ypmed.2016.08.042.

MACKENBACH, J. D., LAKERVELD, J., Van LENTHE, F. J., TEIXEIRA, P. J., COMPERNOLLE, S., De BOURDEAUDHUIJ, I., CHARREIRE, H., OPPERT, J.M., BARDOS, H., GLONTI, K., RUTTER, H., McKEE, M., NIJPELS, G., BRUG, J. (2016). Interactions of individual perceived barriers and neighbourhood destinations with obesity-related behaviours in Europe. Obesity Reviews, 17, 68-80. DOI: https:// doi.org/10.1111/obr.12374.

MARQUET, O., MIRALLES-GUASCH, C. (2015). The walkable city and the importance of the proximity environments for Barcelona's everyday mobility. Cities, 42, 258-266. DOI: https://doi.org/10.1016/j.cities.2014.10.012.

MARTÍNEZ-MARTÍNEZ, O. A., RAMÍREZ-LÓPEZ, A. (2018). Walkability and the built environment: Validation of the Neighborhood Environment Walkability Scale (NEWS) for urban areas in Mexico. Quality \& Quantity, 52, 703-718. DOI: https:// doi.org/10.1007/s11135-017-0483-X.

MELIA, S. (2009) Potential for carfree development in the UK. PhD Thesis, University of the West of England, Bristol.

MITÁŠ, J., FRÖMEL, K., HORÁK, S., NYKODÝM, J., RACEK, O., ŘEPKA, E., ŠEBRLE, D., BLÁHA, L., ALEŚ SUCHOMEL, A., FELTLOVÂ, D., FOJTÍK, I., VALACH, P., KLOBOUK, T. (2013). Self-reported physical activity in perceived neighborhood in Czech adults-national study. Acta Gymnica, 43(2), 23-30. DOI: 10.5507/ag.2013.009.

MITÁS̆, J., RUBIN, L., NYKODYM, J., REPKA, E., FELTLOVA, D., SUCHOMEL, A., BLAHA, L., VALACH, P., KLIMTOVA, H., RACEK, O., SCHUSTER, J., FRÖMEL, K. (2018). Neighborhood walkability and physical activity of Czech adolescents. Journal of Physical Activity \& Health,15(10),181-181.

MITÁS S, J., SAS-NOWOSIELSKI, K., GROFFIK, D., FRÖMEL, K. (2018). The safety of the neighborhood environment and physical activity in Czech and Polish adolescents. International Journal of Environmental Research and Public Health, 15, 126. DOI: https://doi.org/10.3390/ijerph15010126.

MOKHTARIAN, P. L., CAO, X. (2008). Examining the impacts of residential selection on travel behaviour: A focus on methodologies. Transportation Research Part B, 42, 204228. DOI: https://doi.org/10.1016/j.trb.2007.07.006.

MORAN, M. R., EIZENBERG, E., PLAUT, P. (2017). Getting to know a place: Built environment walkability and children's spatial representation of their home-school (h-s) route. International Journal of Environmental Research and Public Health, 14, 607. DOI: https://doi.org/10.3390/ijerph14060607.

MORRIS, D., ENOCH, M. P., PITFIELD, D. E., ISON, S. G. (2009). Car-free development through UK community travel plans. Proceedings of the Institution of Civil Engineers: Urban Design and Planning, 162, 19-27. DOI: https://doi.org/10.1680/ udap.2009.162.1.19.

MOURA, F., CAMBRA, P., GONÇALVES, A. B. (2017). Measuring walkability for distinct pedestrian groups with a participatory assessment method: A case study in Lisbon. Landscape and Urban Planning, 157, 282-296. DOI: https://doi.org/10.1016/ j.landurbplan.2016.07.002.

MUDROŇ, I., PACHTA, M. (2013). Pedestrian network design and optimisation based on pedestrian shortcuts and needs. GIS Ostrava, 175-184.

NÆSS, P. (2009). Residential self-selection and appropriate control variables in land use: Travel studies. Transport Reviews, 29, 293-324. DOI: https://doi.org/ 10.1080/01441640802710812.

NG, S., LAU, W., BROWN, F., TAM, E., LAO, M., BOOTH, V. (2015). Walkable city, living streets. In Baptista, P., ed. Quality of Life. Macau (East-West Institute of Advance Studies), pp. 201-211. 
NIEUWENHUIJSEN, M. J., KHREIS, H. (2016). Car free cities: pathway to healthy urban living. Environment International, 94, 251-262. DOI: https://doi.org/10.1016/ j.envint.2016.05.032.

NORDH, H., VISTAD, O. I., SKÅR, M., WOLD, L. C., BÆRUM, K. M. (2017). Walking as urban outdoor recreation: Public health for everyone. Journal of Outdoor Recreation and Tourism, 20, 60-66. DOI: https://doi.org/10.1016/j.jort.2017.09.005.

OLSZEWSKI, P. S. (2007). Singapore motorisation restraint and its implications on travel behaviour and urban sustainability. Transportation, 34, 319. DOI: https:// doi.org/10.1007/s11116-007-9115-y.

OWEN, N., CERIN, E., LESLIE, E., COFFEE, N., FRANK, L. D., BAUMAN, A. E., HUGO, G., GRAEME, H., SAELENS, B. E., SALLIS, J. F. (2007). Neighborhood walkability and the walking behaviour of Australian adults. American Journal of Preventive Medicine, 33, 387-395. DOI: https://doi.org/10.1016/j.amepre.2007.07.025.

OWEN, N., SUGIYAMA, T., KOOHSARI, M. J., De BOURDEAUDHUIJ, I., HADGRAFT, N., OYEYEMI, A., AGUINAGA,-ONTOSO, I., MITÁŠ, J., TROELSEN, J., DAVEY, R., SCHOFIELD, G., CAIN, K. L., SARMIENTO, O. L., REIS, R., SALVO, D., MACFARLANE, D. J., SALLIS, J. F., CERIN, E. (2018). Associations of neighborhood environmental attributes with adults' objectively-assessed sedentary time: IPEN adult multi-country study. Preventive Medicine, 115, 126-133. DOI: https:// doi.org/10.1016/j.ypmed.2018.08.023.

PELCLOVÁ, J., FRÖMEL, K., CUBEREK, R. (2014). Gender-specific associations between perceived neighbourhood walkability and meeting walking recommendations when walking for transport and recreation for Czech inhabitants over 50 years of age. International Journal of Environmental Research and Public Health, 11(1), 527-536. DOI: https://doi.org/10.3390/ijerph110100527.

PELCLOVA, J., FRÖMEL, K., BLÁHA, L., ZAJĄC-GAWLAK, I., TLUČÁKOVÁ, L. (2012). Neighborhood environment and walking for transport and recreation in Central European older adults. Acta Gymnica, 42(4), 49-56. DOI: 10.5507/ag.2012.023.

POJANI, E., Van ACKER, V., POJANI, D. (2018). Cars as a status symbol: Youth attitudes toward sustainable transport in a post-socialist city. Transportation Research Part F: Traffic Psychology and Behaviour, 58, 210-227. DOI: https://doi.org/10.1016/ j.trf.2018.06.003.

PORĘBSKA, A., RIZZI, P., OTSUKI, S., SHIROTSUKI, M. (2019). Walkability and resilience: A qualitative approach to design for risk reduction. Sustainability, 11, 2878. DOI: https://doi.org/10.3390/su11102878.

PORTA, S., RENNE, J. L. (2005). Linking urban design to sustainability: formal indicators of social urban sustainability field research in Perth, Western Australia. Urban Design International, 10, 51-64. DOI: https://doi.org/10.1057/palgrave.udi.9000136.

QURESHI, S., SHAIKH, J. M., MEMON, S. A. (2018). Residents's subjective assessment of walkability attributes in objectively assessed neighbourhoods. Mehran University Research Journal of Engineering and Technology, 37, 673-680. DOI: https:// doi.org/10.22581/muet1982.1803.20.

RAFIEMANZELAT, R., EMADI, M. I., KAMALI, A. J. (2017). City sustainability: The influence of walkability on built environments. Transportation Research Procedia, 24, 97-104. DOI: 10.1016/j.trpro.2017.05.074.

RICE, R. M., ABURIZAIZA, A. O., RICE, M. T., QIN, H. (2016). Position validation in crowdsourced accessibility mapping. Cartographica: The International Journal for Geographic Information and Geovisualization, 51(2), 55-66. DOI: 10.3138/cart.51.2.3143.

RIŚOVÁ, K., SLÁDEKOVÁ MADAJOVÁ, M. (2020). Gender differences in a walking environment safety perception: A case study in a small town of Banská Bystrica (Slovakia). Journal of Transport Geography, 85, 102723. DOI: https://doi.org/10.1016/ j.jtrangeo.2020.102723.

ROBINSON, O., TAMAYO, I., De CASTRO, M., VALENTIN, A., GIORGISALLEMAND, L., KROG, N. H., AASVANG, G. M., AMBROS, A., BALLESTER., F., BIRD, P., CHATZI, L., CIRACH, M., DEDDELĖ, A., DONAIRE-GONZALES, D., 
GRAŽULEVICIENE, R., IAKOVIDIS, M., IBARLUZEA, J., KAMPOURI, M., LEPEULE, J., MAITRE, L., McEACHAN, R., OFTEDAL, B., SIROUX, V., SLAMA, R., STEPHANOU, E. G., SUNYER, J., URQUIZA, J., WEYDE, K. V., WRIGHT, J., VRIJHEID, M., NIEUWENHUIJSEN, M., BASAGANA, X. (2018). The urban exposome during pregnancy and its socioeconomic determinants. Environmental Health Perspectives, 126, 077005. DOI: https://doi.org/10.1289/EHP2862.

RODA, C., CHARREIRE, H., FEUILLET, T., MACKENBACH, J. D., COMPERNOLLE, S., GLONTI, K., REBAH, B., BARDOS., H., RUTTER., H., McKEE, M., De BOURDEAUDHUIJ, I., BRUG, J., LAKERVELD, J., OPPERT, J. M. (2016). Mismatch between perceived and objectively measured environmental obesogenic features in European neighbourhoods. Obesity Reviews, 17, 31-41. DOI: https://doi.org/10.1111/ obr.12376.

RODIER, C., SHAHEEN, S. A. (2003). Carsharing and carefree housing: Predicted travel, emission, and economic benefits. Proceedings of the 83 th Annual Meeting of the Transportation Research Board, 1-18.

ROSENBERG, D., DING, D., SALLIS, J. F., KERR, J., NORMAN, G. J., DURANT, N., HARRIS, S. K., SAELENS, B. E. (2009). Neighborhood environment walkability scale for youth (NEWS-Y): Reliability and relationship with physical activity. Preventive Medicine, 49, 213-218. DOI: https://doi.org/10.1016/j.ypmed.2009.07.011.

ROSHAN, G. R., SHAHRAKI, S. Z., SAURI, D., BORNA, R. (2010). Urban sprawl and climatic changes in Tehran. Iranian Journal of Environmental Health Science \& Engineering, 7,43 .

ROUTHIER, F., MORTENSON, W. B., DEMERS, L., MAHMOOD, A., CHAUDHURY, H., GINIS, K. A. M., MILLER, W. C. (2019). Mobility and participation of people with disabilities using mobility assistive technologies: Protocol for a mixed-methods study. JMIR Research Protocols, 8, e12089. DOI: 10.2196/12089.

RUBÍN, L., MITÁŠ, J., DYGRÝN, J., ŚMÍDA, J., GÁBOR, L., PÁTEK, A. (2015). Active commuting of the inhabitants of Liberec city in low and high walkability areas. Acta Gymnica, 45, 195-202. DOI: 10.5507/ag.2015.023.

SAELENS, B. E., SALLIS, J. F., FRANK, L. D. (2003). Environmental correlates of walking and cycling: findings from the transportation, urban design, and planning literatures. Annals of Behavioral Medicine, 25, 80-91. DOI: https://doi.org/10.1207/ S15324796ABM2502 03.

SALVO, D., REIS, R. S., STEIN, A. D., RIVERA, J., MARTORELL, R., PRATT, M. (2014). Peer reviewed: Characteristics of the built environment in relation to objectively measured physical activity among Mexican adults, 2011. Preventing Chronic Disease, 147(11), 11-26. DOI: $10.5888 /$ pcd11.140047.

SCHEINER, J., HOLZ-RAU, C. (2007). Travel mode choice: affected by objective or subjective determinants? Transportation, 34, 487-511. DOI: https://doi.org/10.1007/s11116 -007-9112-1.

SIGMUNDOVÁ, D., EL ANSARI, W., SIGMUND, E. (2011). Neighbourhood environment correlates of physical activity: A study of eight Czech regional towns. International Journal of Environmental Research and Public Health, 8, 341-357. DOI: https:// doi.org/10.3390/ijerph8020341.

SILVA, C. D., VIEGAS, I., PANAGOPOULOS, T., BELL, S. (2018). Environmental justice in accessibility to green infrastructure in two European cities. Land, 7, 134. DOI: https://doi.org/10.3390/land7040134.

SOFKOVÁ, T., PRIDALOVÁ, M., MITÁS, J., PELCLOVÁ, J. (2013). The level of neighborhood walkability in a place of residence and its effect on body composition in obese and overweight women. Central European Journal of Public Health, 21, 184.

SONG, Y. (2005). Smart growth and urban development pattern: A comparative study. International Regional Science Review, 28, 239-265. DOI: https://doi.org/ $10.1177 / 0160017604273854$. 
SONI, N., SONI, N. (2016). Benefits of pedestrianization and warrants to pedestrianize an area. Land Use Policy, 57, 139-150. DOI: https://doi.org/10.1016/j.landusepol. 2016.05.009.

SOUTHWORTH, M. (1997). Walkable suburbs? An evaluation of neotraditional communities at the urban edge. Journal of the American Planning Association, 63, 28-44. DOI: https://doi.org/10.1080/01944369708975722.

SOUTHWORTH, M. (2005). Designing the walkable city. Journal of Urban Planning and Development, 131，246-257. DOI: https://doi.org/10.1061/(ASCE)0733-9488(2005) 131:4(246).

SOUTHWORTH, M., BEN-JOSEPH, E. (1995). Street standards and the shaping of suburbia. Journal of the American Planning Association, 61, 65-81. DOI: https:// doi.org/10.1080/01944369508975620.

SOUTHWORTH, M., OWENS, P. M. (1993). The evolving metropolis studies of community, street form at the urban edge. Journal of the American Planning Association, 59, 271-287. DOI: https://doi.org/10.1080/01944369308975880.

STAFFORD, L., BALDWIN, C. (2018). Planning walkable neighborhoods: Are we overlooking diversity in abilities and ages? Journal of Planning Literature, 33, 17-30. DOI: https://doi.org/10.1177/0885412217704649.

STEG, L., VLEK, C., SLOTEGRAAF, G. (2001). Instrumental-reasoned and symbolicaffective motives for using a motor car. Transportation research part F: Traffic Psychology and Behaviour, 4, 151-169. DOI: https://doi.org/10.1016/S1369-8478(01)00020-1.

STOCKTON, J. C., DUKE-WILLIAMS, O., STAMATAKIS, E., MINDELL, J. S., BRUNNER, E. J., SHELTON, N. J. (2016). Development of a novel walkability index for London, United Kingdom: cross-sectional application to the Whitehall II Study. BMC Public Health, 16, 416. DOI: https://doi.org/10.1186/s12889-016-3012-2.

STROHMEIER, F. (2016). Barriers and their influence on the mobility behaviour of elder pedestrians in urban areas: challenges and best practice for walkability in the city of Vienna. Transportation Research Procedia, 14, 1134-1143. DOI: https://doi.org/ 10.1016/j.trpro.2016.05.184.

SUN, Z., BELL, S., SCOTT, I., QIAN, J. (2020a). Everyday use of urban street spaces: the spatio-temporal relations between pedestrians and street vendors: a case study in Yuncheng, China. Landscape Research, 45, 292-309. DOI: https://doi.org/10.1080/ 01426397.2019.1646231.

SUN, Z., LAI, K. Y., BELL, S., SCOTT, I., ZHANG, X. (2020b). Exploring the associations of walking behaviour with neighborhood environments by different life stages: a cross-sectional study in a smaller Chinese city. International Journal of Environmental Research and Public Health, 17, 237. DOI: https://doi.org/10.3390/ijerph17010237.

SZÜCS, P., LUKOVICS, M., KÉZY, B. (2017). Opportunities for walkability in Szeged and Valencia. Regional Statistics, 7, 152-178. DOI: 10.15196/RS07109.

TIRAN, J., LAKNER, M., DROBNE, S. (2019). Modelling walking accessibility: A case study of Ljubljana, Slovenia. Moravian Geographical Reports, 27, 194-206. DOI: https://doi.org/10.2478/mgr-2019-0015.

TONG, X., WANG, Y., CHAN, E. H. (2016). International research trends and methods for walkability and their enlightenment in China. Procedia Environmental Sciences, 36, 130-137. DOI: https://doi.org/10.1016/j.proenv.2016.09.023.

TSIOMPRAS, A. B., PHOTIS, Y. N. (2017). What matters when it comes to "Walk and the city"? Defining a weighted GIS-based walkability index. Transportation Research Procedia, 24, 523-530. DOI: https://doi.org/10.1016/j.trpro.2017.06.001.

TURON, K., CZECH, P., JUZEK, M. (2017). The concept of a walkable city as an alternative form of urban mobility. Zeszyty Naukowe. Transport/Politechnika Slaska, 95, 223230. DOI: 10.20858/sjsutst.2017.95.20.

Van DYCK, D., CARDON, G., DEFORCHE, B., OWEN, N., De BOURDEAUDHUIJ, I. (2011). Relationships between neighborhood walkability and adults' physical activity: 
How important is residential self-selection? Health \& Place, 17, 1011-1014. DOI: https://doi.org/10.1016/j.healthplace.2011.05.005.

Van HOOF, J., KAZAK, J. K., PEREK-BIAŁAS, J. M., PEEK, S. (2018). The challenges of urban ageing: Making cities age-friendly in Europe. International Journal of Environmental Research and Public Health, 15, 2473. DOI: https://doi.org/10.3390/ ijerph15112473.

WANG, H., YANG, Y. (2019). Neighbourhood walkability: A review and bibliometric analysis. Cities, 93, 43-61. DOI: https://doi.org/10.1016/j.cities.2019.04.015.

WEBB, E. A., BELL, S., LACEY, R. E., ABELL, J. G. (2017). Crossing the road in time: Inequalities in older people's walking speeds. Journal of Transport \& Health, 5, 77-83. DOI: https://doi.org/10.1016/j.jth.2017.02.009.

Web of Science Core Collection, [Online]. Available: https://webofknowledge.com/ [accessed 21 May, 2020].

WOOTTON, J. (1999). Replacing the private car. Transport Reviews, 19, 157-175. DOI: https://doi.org/10.1080/014416499295592.

XU, F., LI, J., LIANG, Y., WANG, Z., HONG, X., WARE, R. S., LESLIE, E., SUGIYAMA, T., OWEN, N. (2010). Associations of residential density with adolescents' physical activity in a rapidly urbanizing area of mainland China. Journal of Urban Health, 87, 44-53. DOI: 10.1007/s11524-009-9409-9.

YANG, Y., DIEZ-ROUX, A. V. (2012). Walking distance by trip purpose and population subgroups. American Journal of Preventive Medicine, 43, 11-19. DOI: https:// doi.org/10.1016/j.amepre.2012.03.015.

YU, C. Y., ZHU, X. (2015). Impacts of residential self-selection and built environments on children's walking-to-school behaviours. Environment and Behavior, 47, 268-287. DOI: https://doi.org/10.1177/0013916513500959.

ZANDIEH, R., FLACKE, J., MARTINEZ, J., JONES, P., Van MAARSEVEEN, M. (2017). Do inequalities in neighborhood walkability drive disparities in older adults' outdoor walking? International Journal of Environmental Research and Public Health, 14, 740-761. DOI: https://doi.org/10.3390/ijerph14070740.

ZHANG, J., YU, B., CHIKARAISHI, M. (2014). Interdependences between household residential and car ownership behaviour: a life history analysis. Journal of Transport Geography, 34, 165-174. DOI: https://doi.org/10.1016/j.jtrangeo.2013.12.008.

ZHAO, P. (2010). Sustainable urban expansion and transportation in a growing megacity: Consequences of urban sprawl for mobility on the urban fringe of Beijing. Habitat International, 34, 236-243. DOI: https://doi.org/10.1016/j.habitatint.2009.09.008.

ZHAO, Y., CHUNG, P. K. (2017). Neighborhood environment walkability and healthrelated quality of life among older adults in Hong Kong. Archives of Gerontology and Geriatrics, 73, 182-186. DOI: https://doi.org/10.1016/j.archger.2017.08.003.

Katarína $R i \check{s}$ ová

\section{VÝSKUM SCHODNOSTI: KONCEPT, METÓDY A KRITICKÉ ZHODNOTENIE ŠTÚDIÍ Z POSTSOCIALISTICKÝCH KRAJÍN}

Vhodné podmienky pre pešiu dopravu sú jedným z hlavných pilierov udržatel'nej mestskej mobility (Southworth 2005, Kenworthy 2006, de Freitas Miranda a da Silva 2012 a Rafiemanzelat et al. 2017). Podmienky pre pešiu dopravu sa v anglickej literatúre označujú termínom "walkability". Definované môžu byt' ako miera, do akej prostredie urbanisticky zohl'adňuje potreby chodcov. Slovenský ekvivalent anglického pojmu "walkability" v odbornej literatúre zatial' nie je zaužívaný. Naskytá sa celý rad opisných pomenovaní, ako napríklad "priatel'skost' k chodcom”, "podpora pešieho pohybu", "zohl'adnenie potrieb chodcov" a iné. V odbornom texte však prirodzene hl'adáme kratší výraz, jednoznačne odkazujúci na sledovaný fenomén. Navrhujeme preto pojem schodnost'. Podl'a Krátkeho slovníka slovenského jazyka (Kačala et al. 2003) prídavné meno schodný znamená "vhodný na 
chôdzu”, čím sa tento výraz javí ako najvhodnejší ekvivalent zauživaného anglického termínu. Ústrednou myšlienkou schodnosti je, že dostupnost' nie je jediným faktorom ovplyvňujúcim výber spôsobu dopravy. Namiesto toho ide o súhrn viacerých objektívnych, ako aj subjektívne vnímaných premenných, ktoré nemusia byt' l'ahko kvantifikovatel'né.

Hlavným ciel'om príspevku je otvorit' diskusiu týkajúcu sa vybraných teórií a prístupov k meraniu a kvantifikácii schodnosti, ako aj uskutočnit’ bibliometrickú analýzu a poskytnút' kritické zhodnotenie odbornej literatúry z prostredia postsocialistických krajín, kde predmetný koncept ešte stále nie je dostatočne udomácnený.

Existujú tri hlavné spôsoby merania schodnosti: objektívny, subjektívny a ich kombinácia. Vedecké práce založené na objektívnom prístupe najčastejšie využívajú tzv. 3D model (Cervero a Kockelman 1997), ktorý pracuje s tromi premennými: diverzita (zmiešané využitie zeme), hustota (hustota zal'udnenia, budov či pracovných miest) a dizajn ulíc (hustota križovatiek). Autori 3D modelu dokázali, že tieto premenné podporujú chôdzu v meste. Subjektívny prístup hodnotenia schodnosti sa zameriava na percepciu jednotlivcov a iné behaviorálne premenné, pričom aj v tomto prípade existujú rôzne hodnotiace schémy. Pravdepodobne najpoužívanejšou je NEWS (z anglického New Environment Walkability Scale) pôvodne navrhnutá autormi Saelens et al. (2003), ktorá má podobu dotazníka. Oba spomínané prístupy však čelia kritike. Pri subjektívnom prístupe sú najčastejšie spochybňované dáta udávané samotnými respondentami. Vzniknuté nepresnosti v údajoch môžu viest' k chybám a odchýlkam v meraniach a spôsobit' tak skreslenie zistení (Wang a Yang 2019). V prípade objektívneho prístupu sú zas modely často považované za príliš zjednodušené. Existujú tiež dôkazy, že 3D model nie je univerzálne platný. Autori Xu et al. (2010), Salvo et al. (2014) či Lu et al. (2017) spochybnili tvrdenie, že existuje priama úmernost' medzi hustotou zal'udnenia a pozitívnymi hodnotami schodnosti. Namiesto toho poukazujú na existenciu efektu prahových hodnôt hustoty zal'udnenia, pričom v prostredí niektorých husto zal'udnených ázijských miest sú najpriaznivejšie hodnoty schodnosti v stredne zal'udnených oblastiach. Dalšia kritika objektívneho prístupu sa viaže na teóriu vlastného výberu lokality bývania (residential self-selection). Tá hovorí, že jednotlivci si môžu zvolit’ život v štvrtiach, ktoré odrážajú ich preferencie týkajúce sa aktívneho životného štýlu, no ich správanie nie je výrazne menené (Giles-Corti et al. 2013). Jednoduchšie povedané, fyzicky aktívni jednotlivci si vyberú štvrt' s vyššou schodnost'ou, zatial' čo menej fyzicky aktívnym jednotlivcom stačia aj štvrte vykazujúce nižšiu schodnost'. To by vysvetl'ovalo, prečo obyvatelia objektívne vyššie hodnotených štvrtí chodia viac. Touto teóriou je spochybňovaný štandardný prístup $\mathrm{k}$ štúdiu schodnosti, ktorý pracuje s predpokladom, že podmienky štvrte menia správanie obyvatel'ov - prostredie vhodné pre pešiu dopravu povzbudí jednotlivcov k chôdzi, kým nevhodné prostredie ich chôdzu obmedzí.

Zatial' čo v anglosaskom, latinskoamerickom či východoázijskom prostredí má výskum schodnosti pešieho prostredia už svoju niekol'koročnú tradíciu, v postsocialistických krajinách je zastúpený v minimálnej miere. Kým v raných fázach štúdia sa dôraz kládol najmä na odhal'ovanie objektívnych faktorov ovplyvňujúcich pešiu dopravu, v súčasnosti sa svetový výskum sústred’uje primárne na zdravotné, sociálne a behaviorálne aspekty schodnosti. Je to tak však aj v prípade výskumu autorov z postsocialistických krajín? Na túto otázku sme sa pokúsili zodpovedat' prostredníctvom uskutočnenia bibliometrickej analýzy a kritického zhodnotenia výskumu v predmetnej oblasti.

Analýza bola uskutočnená prostredníctvom štúdia všetkých odborných a vedeckých záznamov z databázy Web of Science Core Collection, ktoré boli k 21. 5. 2020 dohl'adatel'né prostredníctvom kl'účového slova „walkability“ a figuroval pri nich aspoň jeden autor $\mathrm{z}$ niektorej z európskych postsocialistických krajín. Z analýzy vyplynulo, že postsocialistická odborná a vedecká literatúra v oblasti schodnosti sa vyznačuje viacerými limitáciami, na základe ktorých možno definovat' tieto výzvy pre d'alší výskum:

Väčšina príspevkov pracuje s výskumnými otázkami, ktorých ústrednou témou je zdravie obyvatel'ov, pričom neberie do úvahy ostatné perspektívy. Hladanie odpovedí na iné výskumné otázky, ako aj zapojenie viacerých vedných disciplín by mohlo viest’ k obohate- 
niu získaných poznatkov, čím by mohli byt' ozrejmené niektoré súvislosti medzi zdravotnými, priestorovými, environmentálnymi, ekonomickými i spoločenskými aspektmi schodnosti. Taktiež by bolo vhodné, ak by v odborných textoch urbanistov existovala diskusia s relevantnou vedeckou literatúrou.

Ako nedostatok môže byt' vnímaná aj skutočnost', že postsocialistickí autori sa spoliehajú najmä na konzervatívne spôsoby merania schodnosti. Riešením by mohlo byt' hodnotenie širšieho množstva indikátorov, využívanie alternatívnych metód zberu dát, ako aj implementácia kvalitatívnej analýzy.

Väčšina sledovaných prác hodnotí priestor pre peších z pohl'adu štandardizovaného dospelého jedinca a zabúda tak na minoritné vekové skupiny užívatel'ov. Jedincami s rôznymi druhmi zdravotného postihnutia sa postsocialistický výskumníci nevenovali ani $\mathrm{v}$ jednom príspevku. Riešením by mohlo byt' vyhnút' sa štandardizácii indikátorov schodnosti a namiesto toho ich prispôsobit' jedincom s rôznymi schopnost'ami (napr. zdravotne postihnutým), v rôznom veku (malým det’om, adolescentom, dospelým aj seniorom) a s rôznym životným štýlom (napr. rodičia na materskej dovolenke).

Napriek spomenutým nedostatkom, postsocialistický výskum schodnosti sa vyznačuje aj niekol'kými výhodami, napríklad existenciou medzinárodnej spolupráce či uskutočňovaním komparatívnych štúdií. Hoci sa výskum predmetnej oblasti v tomto regióne začal vyvíjat' s časovým oneskorením (prvý záznam v databáze WOS Core Collection je z roku 2010), v budúcnosti má potenciál stat' sa podkladom pre územné plánovanie v oblasti zlepšovania kvality prostredia pre peších.

Article first received: February 2020

Article accepted: August 2020 